Digital Press Social Sciences and Humanities

Strategies for Cultural Transformation: Indonesian Debates of the 1970s and 1980s Revisited

Arndt Graf

Proceeding of 9th International Conference on Nusantara Philosophy (ICNP) Arndt Graf, Fitri Alfariz, M Rodinal Khair Khasri, Rachmad Hidayat, Rokhmat Sairah, Zaid bin Ahmad (eds) 


\title{
Strategies for Cultural Transformation: Indonesian Debates of the 1970s and 1980s Revisited
}

\author{
Arndt Graf \\ Goethe-Universität am Main Institut für Ostasiatische Philologien \\ e-mail: arndtgraf@yahoo.de
}

\begin{abstract}
This contribution investigates the discursive occurrence of key terms of the Indonesian debates about "modernization", "cultural transformation", and "pembaruan" (renewal). The sample consists of the book titles documented in Worldcat.org, from 1945 through 2020. This sample is gathered through various searches and then manually looked through one by one in order to omit duplicates. Selected titles are then further analyzed in a qualitative approach. The evidence generated by this method shows a close temporal link with the so-called "New Order" governments since 1966. This article can therefore serve to further analyze individual elements of New Order discourses on modernization discourse and modernization theory.
\end{abstract}

\section{Keywords}

Indonesia, Mochtar Lubis, modernization discourse, new order

\section{Introduction}

In 1991, during research for my study on the image of the rain forest in the literary works of Mochtar Lubis - Published as a book in German language (Graf 1995a) and as a short English-language summary (Graf 1995b) - , Professor E.U. Kratz from the School of Oriental and African Studies, London, allowed me to use his impressive personal library on the literatures and cultures of Indonesia and the Malay World, by giving helpful comments on how he had organized his collection.

"Here are the shelves with the Indonesian novels, here with the Malay ones, here is poetry from Indonesia, here from Malaysia and Brunei, and here is a strange group of books from Indonesia about 'culture'. I call this group 'budaya'. There are almost no books from Malaysia and Brunei that would fit into that category (Kratz, 1991)."

Many years later, during the sombre time of the Covid-19 pandemic, when I was asked to contribute to the $9^{\text {th }}$ International Conference on Nusantara Philosophy at Universitas Gadjah Mada, I remembered this observation by E.U. Kratz about the phenomenon of a specific Indonesian discourse on culture, modernization and strategies for deep cultural transformation (transformasi budaya), which reportedly was very strong in the 1970s and 1980s. As my own study on Mochtar Lubis had shown, there is indeed a very strong link between his idea of transformasi budaya and some of the core concepts of philosophy, including ontology, rationality, strategies of enlightenment etc. In this regard, revisiting some of these very foundational discourses in the formative years of the New Order might contribute to a better understanding of the deep cultural and social impact that the Covid-19 pandemic has had in Indonesia.

\section{Methods}

As described above, this study departs from the observation and categorization of E.U. Kratz as a collector of literary and cultural publications from Indonesia and the so-called Malay World (mostly Malaysia and Brunei Darussalam). The scope of the collection had an in-built comparative angle which allowed the collector to identify the specific Indonesian dimension of the published discourses on "modernisasi" and 
"transformasi budaya". As E.U. Kratz became a lecturer at Universitas Indonesia after he obtained his PhD at Goethe University Frankfurt in 1971 and before he began to work at SOAS, London in 1977, his collection has for these biographical reasons a strong coverage of the Indonesian publications of the early to mid1970s. My question for this paper is whether the phenomenon described by E.U. Kratz can be assessed beyond a biographical coincidence. For this reason, I am employing in this paper a bibliometric approach based on the worldwide library holdings as documented by Worldcat- Various searches on www.worldcat.org, October and November 2021. More than 10,000 libraries share here information about their holdings, including the very comprehensive collections of Leiden University and Cornell University. As not many Indonesian libraries are yet members of Worldcat, there might be, however, the possibility that Worldcat does not provide the full picture. It is, on the other hand, the best available source for the assessment intended in this paper.

I am aware that Indonesian discourses on cultural difference, e.g. between "East" and "West", "Arjuna" and "Faust" (Sanusi Pane) ${ }^{1}$, modernity, and rationality are already an important part of the intellectual discussions of the 1920s and 1930s, in the so-called generation of "Pujangga Baru" (Angkatan Pujangga Baru). ${ }^{2}$ Also, Dutch authors such as Boeke (1930) with his famous concept of a dual society and dual economy in the Dutch East Indies (dualistische economie), based on the distinction between "modern" and "traditional" are part of the conceptual framings of colonial modernity ${ }^{3}$, which probably also resounded in the Dutch and Malay-language media and fictional genres of the Dutch East Indies. For the limited purpose of this paper, however, I am setting as the starting date of my sample the year of the Indonesian declaration of Independence, 1945, ending the sample with $2020 .{ }^{4} \mathrm{~A}$ further important decision is to limit the included publications to only those in Indonesian language since this way it is most likely to only have voices from Indonesia in the sample, and not non-Indonesians writing about Indonesia by using concepts such as "modern" or "traditional", although certain foreign contributions, e.g. Teeuw's Modern Indonesian Literature (1967), certainly were influential also for the Indonesian-language discourse.

Another deliberate limitation is to focus the sample only on the titles of printed books and not to include articles in newspapers, book chapters, oral communication, manuscripts, films, TV and radio, or communication via the Internet. This (incomplete) list of possibilities is merely intended to demonstrate that Indonesian discourses on modernity and modernization are of course much broader and much more complex than those items covered in my sample. On the other hand, it could be argued that titles of printed books in the period considered reveal that certain themes were at the time of publication considered to be appealing enough to be put prominently in the title. Indirectly, the occurrence of books with titles featuring terms such as "modernisasi" or "transformasi budaya" demonstrate a broader interest in the topic at the time of publication.

\footnotetext{
${ }^{1}$ For Sanusi Pane's views on "Arjuna" and "Faust" in the context of his proposed Manusia baru (new human), including his drama with the same title from 1940, cf. Bodden (1997) and Imma Dwi Minggar Nastiti (2013).

${ }^{2}$ For a useful introduction into Pujangga Baru cf. Foulcher (1980), and more recently, Cohen (2016).

${ }^{3}$ Boeke's concept of "Dual Society" is mostly known to the non-Dutch reading academics through the English translation of 1953.

${ }^{4}$ I conducted a short trial sample before determining on this time period from 1945 to 2002, namely first with no time limits set. When I searched for the dichotomy "lama" and "baroe" in book titles from Indonesia, the result was that "baroe" first appeared in cooking books, e.g. Njonja Johanna (1896), before it eventually also was used for other cultural spheres, such as literature, with the famous journal Poedjangga Baroe (1933-42) being a very prominent example. However, it was not only used for a notion of "colonial modernity", since it also appeared several times in publications during the Japanese occupation, suggesting a "new" spirit within the Greater East Asian Co-Prosperity Sphere, e.g. in S. Ozu: Djiwa baroe (1943) or the journal Sinar baroe: nomor peringatan setahoen Djawa baroe (1943). This Japanese-related or possibly broader Asian horizon of modernity deserves a much closer look and hence is not treated in this paper.
} 


\section{Results and Discussion}

\subsection{Modernisasi}

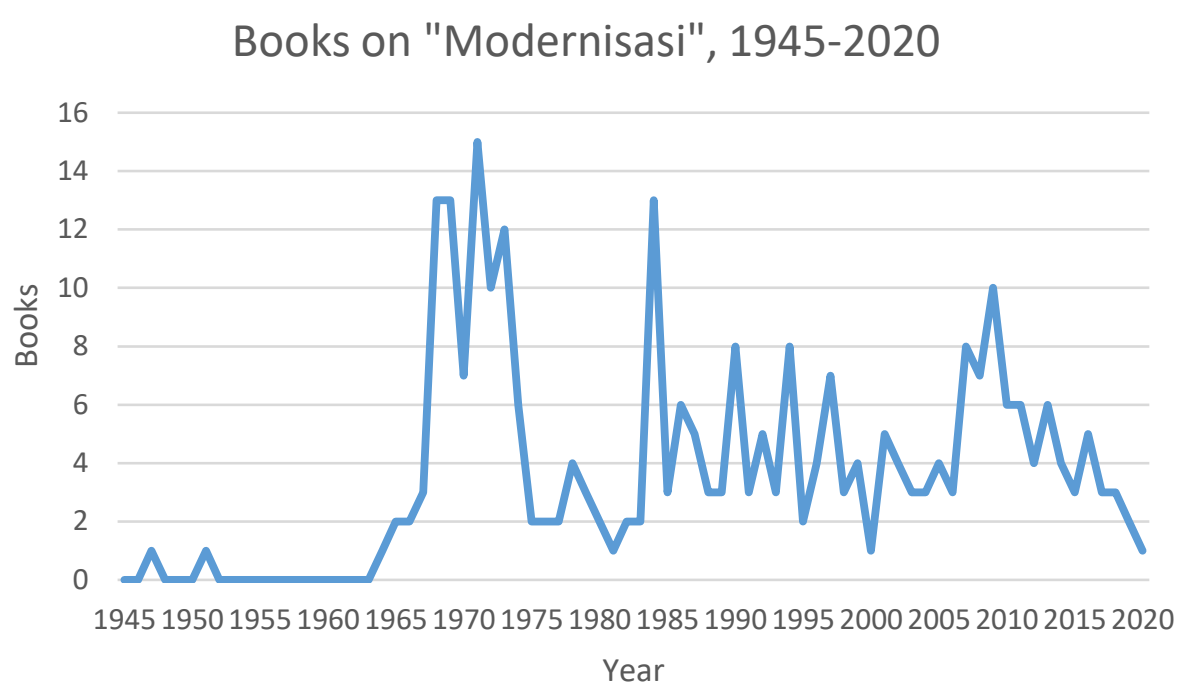

Fig.1 Indonesian publication on "modernisasi”, 1945-2020

My compilation of Worldcat holdings with books in Indonesian language with the term "modernisasi" in the title consists of 277 books, from 1945 through 2020. Interestingly, from 1945 through 1965, only three books on "modernisasi" appeared, namely one on "modernisasi pertanian" (modernization of agriculture) and two on "modernisasi Islam" (modernization of Islam, 1951 and 1964). In contrast, in the following ten years from 1966 through 1975, 85 books on "modernisasi" were published in Indonesia, with peaks in 1968 (13 books), 1969 (13), 1971 (15), 1972 (10) and 1973 (12). Many of these 85 books probably also found their way into the Kratz collection, and let the collector realize that they represented something of interest.

After this massive concentration of books on "modernisasi" in the first ten years of the New Order, the numbers of new books on that topic declined to around two to eight per year in the following three decades. 1984 proved an exception to this trend, when a series of government reports on negative impacts of modernization in many provinces of Indonesia began to appear (Laporan dampak modernisasi pada hubungan kekerabatan di propinsi XYZ (Report on the impact of modernization on kinship relations in province XYZ)). Only several years after the fall of the New Order, the term "modernisasi" became popular again, mostly between 2008 and 2013, with many publications on "modernisasi Islam" (modernization of Islam) or "modernisasi pesantren" (modernization of Islamic boarding-schools). The peak was reached in 2010, with ten such publications. However, the numbers are since declining.

If we have a closer look at the 85 books on "modernisasi" in the first ten years of the New Order, we can identify important authors who popularized the term, including Rosihan Anwar, Gerakan Mahasiswa Kristen Indonesia, Studi Club "Mahasiswa Indonesia”, Nurcholish Madjid, Harsojo, Bachtiar Rifai, Tatang M Natsir, T.B. Simatupang, Ali Moertopo. ${ }^{5}$ From the book titles, one can also see the theoretical link to American modernization theories of the 1960s, e.g. in the publication Laporan mendjelang take off modernisasi desa dalam pelaksanaan PELITA laut (Report about the take-off of modernization in the implementation of the Five-Year Plan concerning the sea), published by the Dinas Perikanan Laut (Agency for Sea Fishery), Sekretariat Pemerintah Daerah Popinsi Djawa Tengah, 1971. The term "take-off" refers here to the Walt Rostow's highly book: The Stages of Economic Growth (1960), in which he distinguishes five stages: 1) the traditional society, 2) the preconditions for take-of, 3) the take-off, 4) the drive to maturity, and 5) the age of high mass-consumption. ${ }^{6}$ Also the publication by a key New Order figure such as General Ali Moertopo (1973) about accelerated modernization in Indonesia refers to this theoretical context, and at the same time to the central political importance of modernization theory for the New Order

\footnotetext{
${ }^{5} \mathrm{Cf}$. the details about these publications in the References below.

${ }^{6}$ Todaro/Smith (2020) give a good introduction into the economic theory of modernization in its historical context.
} 
economic and social strategy. Rostow's concept of the stages of economic growth from 1960 was still part of President Suharto's rhetoric in the 1980s and 90s (cf. e.g. Soeharto 1987).

However, it is important to understand that the discourse on "modernisasi" in the early years of the New Order was not only reflecting and discussing American concepts of modernization theory of the 1950s and 1960s. There were also other sources. Nurcholish Majid very early, in 1968, published his important book Modernisasi adalah rasionalisasi, bukan Westernisasi. Here he points out that Weber's concept of rationalization should be taken into account, since it influenced Talcott Parsons and others when they developed their own contributions to social theory. Majid's book also constitutes an interesting entry point for the philosophical reflection about the deep cultural transformation in Indonesia when the large-scale, all-encompassing development decades of the New Order began. At the same time, the concept of rasionalisasi allows to consider the effects of the state-organized rationalization program across the various cultures and religious communities of Indonesia in a comparative perspective - and to widen the comparative enquiry even further by including other parts of Southeast Asia, e.g. the Malay World (mostly Malaysia and Brunei Darussalam) in a research perspective of Nusantara philosophy.

Having said that, Nurcholish Majid (1968) and with many of his later contributions as a leading Islamic intellectual, also provides us an entry point into specific discourses of modernizing Islam since the late $19^{\text {th }}$ century, when Muhammad Abduh and others became the founding fathers of modernist Islamic movements. For example, Ahmad Dahlan from Yogyakarta and the Indonesian Muhammadiyah movement have in this context of religious modernisasi a very prominent position. In fact, as mentioned above, among the three books with modernisasi in the title published between 1945 and 1965, two focus on modernizing Islam (Bustami Ibrahim 1951) and on modernizing Islamic religious education (Masduqi, 1964).

\subsection{Transformasi Budaya}

Book publications with the keyword "transformasi budaya" begin in 1985 and appear rather evenly every year throughout the entire rest of the period considered here, as Graph 2 illustrates.

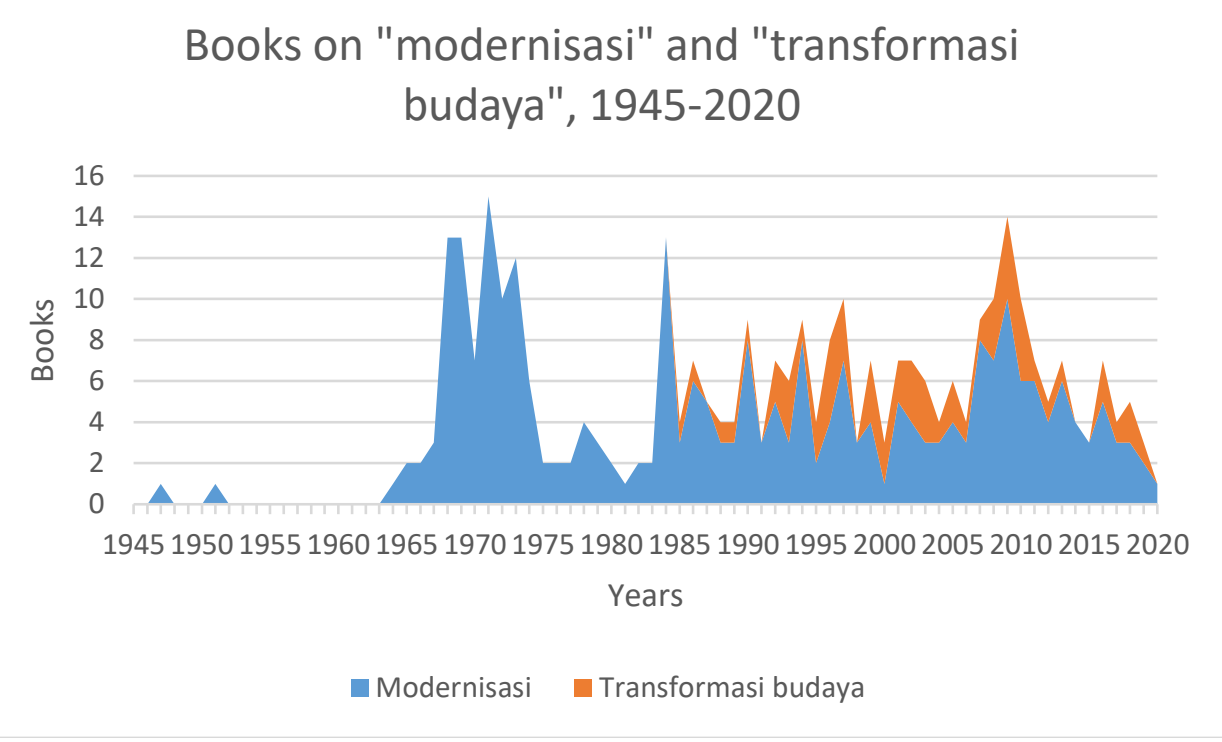

Fig.2 Book publications on "modernisasi" vs "transformasi budaya"

The first book in this current of discourse already continues the specific Islamic viewpoint discussed above: Amrullah Ahmad: Dakwah Islam dan transformasi sosial budaya (1985). Alfian (1986) follows with Transformasi sosial budaya dalam pembangunan nasional, then Mochtar Lubis with Transformasi budaya untuk masa depan (1988), and Umar Kayam with Transformasi budaya kita (1989). Also a book publication by LIPI refers to the keyword transformasi budaya: Industrialisasi dan perubahan social: transformasi nilainilai social budaya menuju masyarakat industri. Studi kasus di propinsi Jawa Timur (1990).

As an example of the related ideas, I elaborate here a bit further on Mochtar Lubis' ideas about whose works I have published earlier (Graf 1995a and 1995b). ${ }^{7}$ As a Muslim Mandailing from Northern Sumatra, Mochtar Lubis (1922-2004) grew up in a social context with modernist Muslim orientations as well as in a modernist school where the teacher would take the students out for excursions into nature. Decades later,

${ }^{7}$ Cf. also Chambert-Loir (1974), Mansyur Semma (2006), and Hill (2010) on Mochtar Lubis' biography and thoughts. 
Mochtar Lubis transformed these personal experiences in his youth novels Penyamun dalam rimba (1972) and, in particular, in the revised version Berkelana dalam rimba (1980). This novel became a best-selling book, with 130,000 copies sold from 1980 through 1992 alone. ${ }^{8}$ Berkelana dalam rimba proposes a deep cultural transformation: away from the belief in spirits and ghosts and a spirited nature towards an understanding of nature, including the wild forest, as part of God's creation, where human beings are given rationality to look at the world scientifically. Based on this strong role of human intellect in a setting of the creation, human beings are now able to not only explore (wild) nature, but also to put it to economic use. Since they no longer are afraid of the spirited nature, they now can even develop new esthetic framings of wild nature, both on an individual basis and as part of a "double-green movement" (as one could call the idea of an Islamic ecological movement from today's perspective ${ }^{9}$ ). This transformasi budaya hence contains very fundamental philosophical shifts in the very basic concepts of reasoning, in particular logic, ontology and cosmology. ${ }^{10}$

\subsection{Pembaruan}

As we have seen so far, Indonesian book publications on "transformasi budaya" begin about 20 years after the big wave of "modernisasi" books were published from 1966 onward. The question arises whether the authors of the foundational years of the New Order not only used the foreign loanword modernisasi, but also, for instance the Malay term pembaruan (renewal). Hence, I repeated my methodology, by conducting another search in Worldcat, manually producing a bibliography, transferring the publication numbers per year into an Excel table and then producing a combined graph of the three keywords so far (Fig 3).

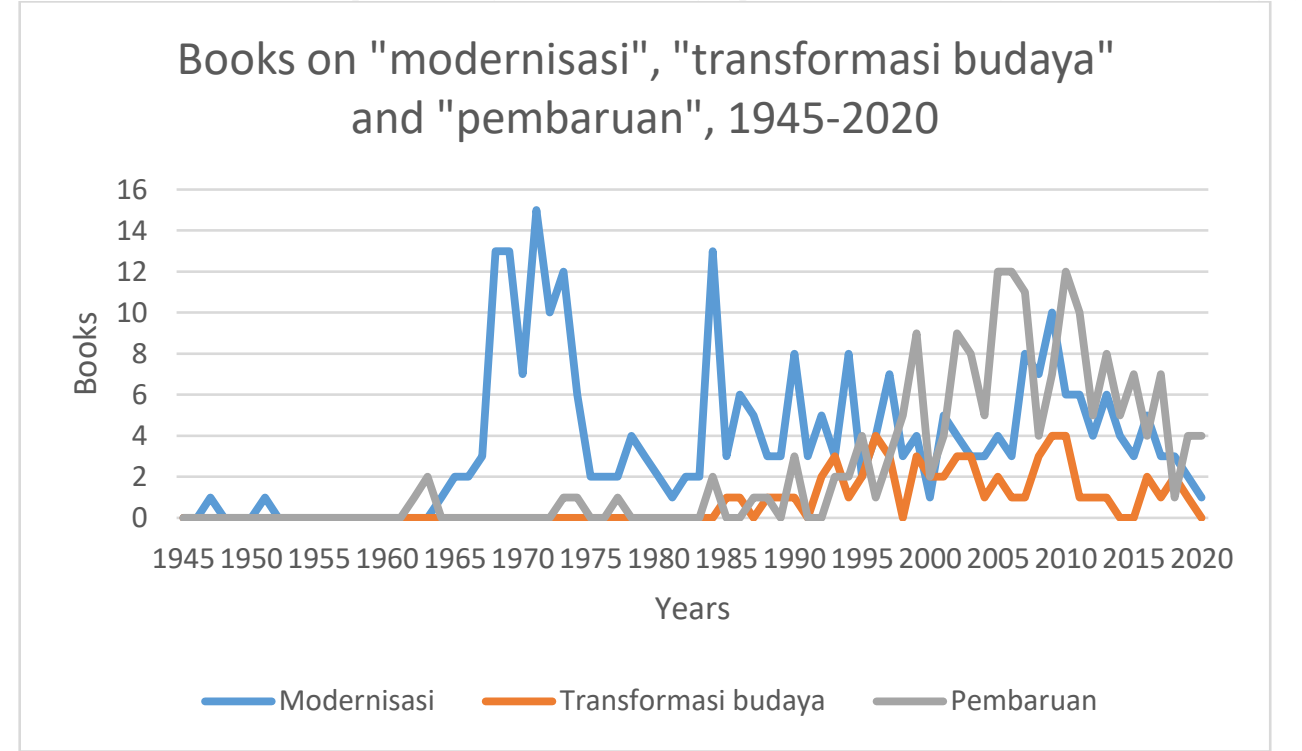

Fig. 3 Indonesian books on "modernisasi", "transformasi budaya" and "pembaruan", 1945-2020

As Graph 3 illustrates, there were indeed a few book publications featuring "pembaruan" in the early 1960s, namely in 1962 and 1963, published by the Jajasan Pembaruan (Partai Komunis Indonesia (1962), Lukman (1963) and Aidit (1963)). ${ }^{11}$ It seems that the term "pembaruan" was used by the Communist Party of Indonesia as a propaganda keyword for "progressive" politics in the PKI view. It is therefore not astonishing that after the change of power and the destruction of the Communist Party, the term "pembaruan" was not popular for a number of years. Only three book publications with "pembaruan" appeared between 1965 and 1984, two of which on "pembaruan pendidikan" (education reforms), namely Mashuri (1973) and Institut Keguruan dan Ilmu Pendidikan (1977).

Only from 1984 on, books on "pembaruan" began to appear, often with a conceptual link to modernist Islam, e.g. A. Shamad Hamid (1984): Islam dan pembaruan: sebuah kajian tentang aliran modern dalam Islam dan permasalahanya, or Hasan Bannā (1987): Konsep pembaruan masyarakat Islam. This current of "pembaruan dan Islam" publications persists through the end of the analyzed period. From the mid-1980s

\footnotetext{
${ }^{8}$ Personal letter of Mochtar Lubis to the author, dated 10 March 1992 (cf. Graf 1995a: 6).

${ }^{9}$ Cf. Graf (2015) and Nilan (2020) for recent contributions on Islamic environmentalism in Indonesia.

${ }^{10}$ Still very helpful for understanding the fundamental, long-term shifts in cosmology over the centuries in the cultural history of the archipelago is Lombard (1990).

${ }^{11}$ For a recent research article on the Jajasan Pembaruan, cf. Roma Dwi Aria Yudiantri (2021).
} 
onward, also a few books on "pembaruan" in the cultural field appeared, e.g. in literature (Nyoman Tusthi Eddy 1984) and in general cultural outlook (Deliar Noer: Perubahan, pembaruan, dan kesadaran menghadapi abad ke-21, 1988). Also in the visual arts, artists such as FX Harsono and thinkers within the literary and visual art world (such as Nirwan Dewanto) began using the term "pembaruan" in the 1980s, even as basis of some of the artistic practice. ${ }^{12}$ In many instances, this relates to Gerakan Seni Rupa Baru and its deep impact on contemporary Indonesian art (Rath 2011). Therefore, I will be looking at the books with "baru" in the title below.

In addition, from 1990 onward, book publications on political reforms began to appear, first in two book titles on Mikhail Gorbachev, namely Soepeno Soemardjo (1990): Mikhail Gorbachev tokoh pembaruan abad ini Soedjati Djiwandono (1990): Pengaruh pembaruan Gorbachev di dunia komunis. As Graph 3 shows, became the term "pembaruan" very popular in the first years of the reformasi era, from around 1998. Its peak was in the decade between 2002 and 2011 when 90 books with the title "pembaruan" appeared. In these years, also "modernisasi" had a second wave of popularity, being used almost synonymous with "reformasi". However, both the "pembaruan" and the "modernisasi" discourse decreased steadily in the subsequent years until the end of the sample. Between 2012 and 2021, only 48 book titles with "pembaruan" appeared.

\subsection{Baru}

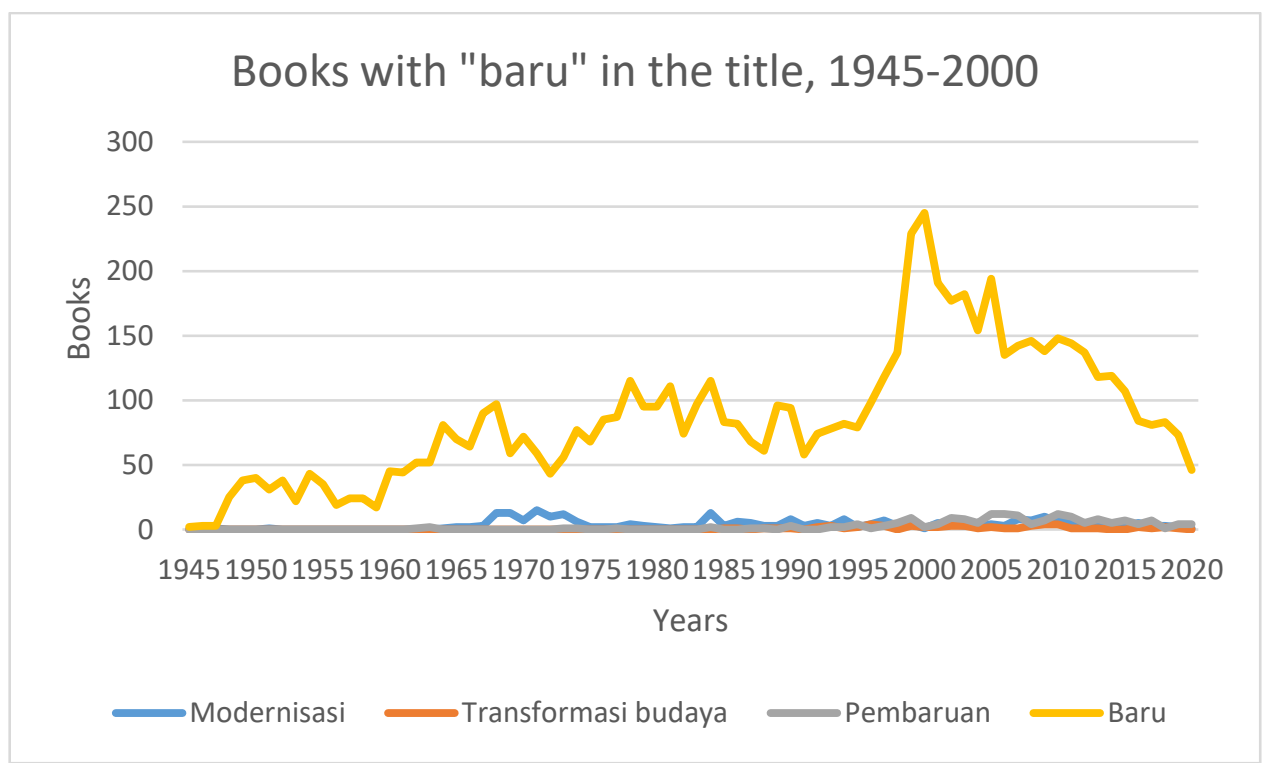

Fig 4. Books with "baru" in the title in comparison, 1945-2000

As Graph 4 shows, was "baru" (new) an element in book publications during the entire time frame of the sample, from 1945 through 2020. There were always many more books with just "baru" in the title than with the more specific terms "modernisasi", "transformasi budaya", and "pembaruan". As the total number of books with "baru" is 6,548, a systematic qualitative analysis based on individual publications is rather difficult. Instead, a quantitative look at broader patterns of the sample, combined with a few more or less randomly selected qualitative examples appears more useful.

From 1945 until 1965, Graph 4 shows two periods with an increased popularity of "baru". He first one starts around 1947 and extends until around 1954/55. An interpretation could be that here foundational discourses on the newly formed country took place, and "baru" in a title could signify a break with time before 1945, especially the colonial experience and the Japanese occupation. This first wave of titles on the "baru" was followed by a few years with less intensive book discourses, from around 1955 through 1959/60. From 1960 through 1965, book publications on "baru" increased every year. A question for a future enquiry could be whether "baru" in these years was associated with "progressive" propaganda notions (and/or an ideological conflict as to who would correctly understand "baru"), as observed above with "pembaruan".

In the early years of the New Order (Orde Baru!), "baru" appears rather often in book publication titles, with 484 publications from 1966 to 1972, where the curve in Graph 4 shows the lowest point in the New Order. Until the mid-1990s, there was a constant flow of books on "baru", while the end of the 1990s and

\footnotetext{
12 Personal communication with Amanda K. Rath, Jan. 2022.
} 
early 2000s saw an extreme rise in the popularity of books with "baru" in their title. One can safely assume that this was due to the popularity of reformasi themes in Indonesian society at that time. However, just as with "modernisasi", "transformasi budaya", and "pembaruan", that fascination decreased steadily until 2020. This leads to the final question, whether this can be related to discourses on culture (budaya), as observed by E.U. Kratz.

\subsection{Budaya}

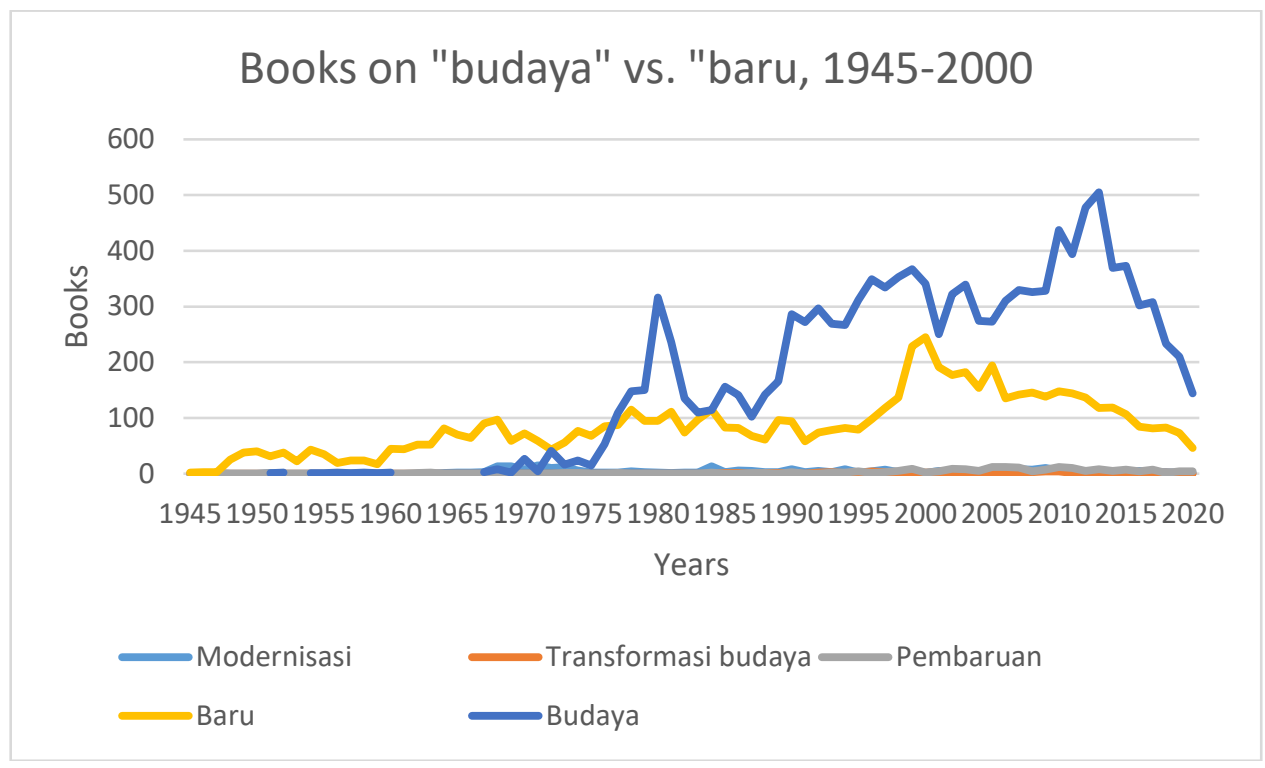

Fig.5 Books with "budaya" in the title in comparison, 1945-2000

Graph 6 finally juxtaposes the publication numbers of books with "budaya" in the title with those with "baru", "modernisasi", "transformasi budaya", "pembaruan", and "baru". In fact, it is apparent that since the beginning of the so-called New Order in 1966, "budaya" has become an important keyword for book publications in Indonesia. From 1945 through 1965, a total of 18 books on "budaya" appeared, while in the following 20 years, from 1965 through 1985, the total was 1,667 books. No wonder that Prof. E.U. Kratz would be able to establish a category "budaya" in his library. Until 1998, another 3,290 books followed, bringing the total to 4,957 books on "budaya" during the New Order. The search for the reasons for this astonishing discursive productivity might be more complex than rather ascribing it merely to a "neotraditional ideology" of the New Order, as opposed to the class-conscious discourse of the Left in the Soekarno years. Clearly, discussions on social conflict and class struggle were banned in the New Order, as part of the SARA taboo (suku, agama, ras, antar-golongan - ethnic goup, religion, race, class conflict). In addition, however, one has to see that the massive education expansion during the Soeharto years led to millions of highly educated Indonesians who would be interested in reading and writing about culture in many dimensions: local, regional, and national culture, cultural transformation in the wake of the modernization of the country (cf. above), finally cultural heritage as orientational framework of the emerging middle classes of the 1980s and 1990s. And also, cultural themes an inspiration for one's own ideological orientation, especially in times of personal and social crisis, for instance in the wave of cultural globalization since the 1990s. Interestingly, namely, Graph 5 shows that the peak of book publications on "budaya" was not during the New Order, but after. In the 21 years from 1999 through 2020, 7,213 books on "budaya" appeared - more than in the entire New Order that had lasted 32 years (from 1966-1998).

\section{Conclusion}

This paper departed from the observation of Prof. E.U. Kratz that in his personal library on Indonesian and Malay literatures and cultures he had amassed a number of books that discuss and theorize aspects of culture at large, including cultural change. This group of books he called the "budaya" category. The first intention of this paper was to examine whether that "budaya" category only existed by a coincidence in that private book collection, or whether I could be indeed identified as such in a much more comprehensive collection of books. For this purpose, I employed various searches in Worldcat, which documents the 
holdings of more than 10,000 libraries worldwide, including the massive collections in Leiden and at Cornell University. In order to operationalize my research question, I conducted keyword searches for "modernisasi", "transformasi budaya", and "pembaruan" in titles of book publications in Indonesian language between 1945 and 2021. The first main finding is that "modernisasi" did in fact exist as a topic prior to 1966, as can be seen in "modernisasi Islam" or "modernisasi pertanian", but its real discursive boom started with the change of power in 1965/66. In the first ten years of the New Order, numerous publications on "modernisasi" appeared. From the book titles, it is apparent that the central importance of modernization theory (as well as other related theories on rationalization) for the economic and social strategy of the New Order contributed largely to this sudden significance of "modernisasi". A second main current of the "modernisasi" discourse is to be found in discourses on modernist Islam - before, during, and after the New Order. "Transformasi budaya" began to appear as a keyword of book titles about 20 years after the "modernisasi" discourse of New Order developmentalism, namely in the mid-1980s. It was mostly intellectuals such as Mochtar Lubis, Alfian, and Umar Kayam who reflected on the deep cultural changes brought to Indonesia by the "modernisasi" programs. Finally, "pembaruan" seemed to be a term employed by the Communist Party of Indonesia, e.g. for its publishing house "Jajasan Pembaruan", and hence was rather unpopular as a book title after 1965 for about 20 years. From the mid-1980s onward, it started to be used in association with Islam (mostly modernist Islam), and from 1990 on also in the sense of deep political reform, departing from books on Mikhail Gorbachev. After reformasi in 1998, "pembaruan" experienced a decade of great popularity, together with "modernisasi" (in the sense of "reformasi"). In the last ten years in the sample, its popularity continuously decreased - just as was the case with "baru" (new), although on a much larger scale.

At the same time, however, the analysis of book publication in Indonesian language from 1965-2020 reveals another, highly interesting trend: "budaya" (culture) is indeed a highly prominent topic since the beginning of the New Order. As much as it might have been of ideological use in the in the post-PKI years after 1966, this paper argues that the popularity of the topic might be due to a number of reasons, including its political significance in multi-cultural Indonesia, where "culture" can be used both as a divisive and a unifying approach by multiple actors. Since the annual publications on "budaya" in the years since from 1999 to 2020 far outnumber the output of the New Order years, it is argued that a part of the reason for the popularity of the topic in Indonesia might be also due to the changing cultural horizons brought about with the wave of globalization since the 1990s.

In conclusion, the findings of this paper confirm the mentioned observation of Prof. E.U. Kratz. There is indeed a specific Indonesian discourse on "culture" (budaya), with an enormous amount of book titles on "budaya" since the early New Order. In the first ten years of the New Order, publications mostly applied the concept of "modernisasi" to all sorts of aspects of technical, social, cultural, economic, and political life, while from the mid-1980s onward, several highly influential intellectuals such as Mochtar Lubis, Alfian, or Umar Kayam reflected about the deep cultural changes brought about "modernisasi" - and deemed necessary on a normative basis by these authors. In this regard, the "budaya" discourse of these publications during the New Order can be regarded as highly informative for inquiries not only from the social sciences, but also the humanities, including fields of research such as Nusantara philosophy.

\section{References}

Adi, A. (2020). Etika Lingkungan Dalam Gaguritan Kabresihan. Dharma Duta, 17(2). https://doi.org/10.33363/dd.v17i2.349

Aidit, D.N. (1963). Berani, berani, sekali lagi berani! (Laporan Politik Ketua CC PKI kepada Sidang Pleno I CC PKI, disampaikan pada tanggal 10 February 1963). Djakarta: Jajasan Pembaruan.

Alfian. (1986). Transformasi Sosial Budaya dalam Pembangunan Nasional. Jakarta: Penerbit Universitas Indonesia (UI-Press).

Ahmad, Amrullah. (1985). Dakwah Islam dan Transformasi Sosial Budaya. Yogyakarta: Pusat Latihan, Penelitian dan Pengembangan Masyarakat (PLP2M).

Anwar, Rosihan. (1965). Serba Aspect Pembangunan dan Modernisasi. Jakarta: Study Group Mahasiswa Tjempaka Putih. 
Bannā, Hasan. (1987). Konsep Pembaruan Masyarakat Islam. Jakarta: Media Da'wah.

Bodden, M. H. (1997). Utopia and The Shadow of Nationalism; The Plays of Sanusi Pane 1928-1940. Bijdragen Tot de Taal-, Land- En Volkenkunde / Journal of the Humanities and Social Sciences of Southeast Asia, 153(3), 332-355. https://doi.org/10.1163/22134379-90003927

Boeke, J. H. (1953). Economics and Economic Policy of Dual Societies as Exemplified by Indonesia. Haarlem: H.D. Tjenk Willink.

Ibrahim, Bustami. (1951). Modernisasi dalam Islam. Medan: Madju.

Chambert-Loir, Henri. (1974). Mochtar Lubis: Une Vision de l'Indonésie Contemporaine. Paris: Publications de de l'École Française d'Extrême-Orient.

Cohen, Matthew. (2016). Inventing the Performing Arts Modernity and Tradition in Colonial Indonesia Honolulu: University of Hawai'i Press.

Dinas Perikanan Laut (Agency for Sea Fishery). (1971). Laporan mendjelang take off modernisasi desa dalam pelaksanaan PELITA laut (Report about the take-off of modernization in the implementation of the Five-Year Plan concerning the sea).

Djiwandono, J Soedjati. (1990). Pengaruh Pembaruan Gorbachev di Dunia Komunis. Jakarta: Centre for Strategic and International Studies.

Foulcher, Keith. (1980). Pujangga Baru: literature and nationalism in Indonesia, 1933-1942. Jakarta: GMKI.

Graf, Arndt. (1995a). Der indonesische Regenwald im Prozeß der Entmagisierung. Zum Wandel eines literarischen Topos' bei Mochtar Lubis (The Indonesian rain forest in the process of dymystification. On the change of a literary trope in Mochtar Lubis' works). Hamburg: Lit (Austronesiana, 3).

Graf, Arndt. (1995b). Attitudes Towards the Rain Forest in the Literary Works of Mochtar Lubis. Indonesia Circle, 65, 32-41.

Arndt Graf. (n.d.). Fukushima' and the Muslim anti-nuclear movement in Indonesia. In Thomas M. Bohn, Thomas Feldhoff, Lisette Gebhardt, \& Arndt Graf (Eds.), The Impact of Disaster. Social and Cultural Approaches to Fukushima and Chernobyl. Berlin: EB.

Harsojo. (1969). Tradisi dan Modernisasi dalam Pembangunan Masjarakat Indonesia. Bandung: Jajasan Penerbitan, Universitas Padjadjaran.

Hill, David T. (2010). Journalism and politics in Ondonesia. A critical biography of Mochtar Lubis (19222004) as editor and author. London; New York: Routledge.

Nastiti, Imma Dwi Minggar. (2013). Pemikiran Sanusi Pane dalam menumbuhkan kesadaran nasional dan kebudayaan nasional Indonesia, 1930-1942. AVATARA, 1(3), 561-570.

Institut Keguruan dan Ilmu Pendidikan. (1977). Pendidikan dan Pembangunan: Tantangan-Tantangan bagi Pembaruan Pendidikan. Bandung: Institut Keguruan dan Ilmu Pendidikan.

Kayam, Umar. (1989). Transformasi Budaya Kita. Yogyakarta: Universitas Gadjah Mada.

LIPI. (1990). Industrialisasi dan perubahan sosial: transformasi nilai-nilai sosial budaya menuju masyarakat industri studi kasus di propinsi Jawa Timur. Jakarta: Lembaga Ilmu Pengetahuan Indonesia.

Lombard, Denys. (1990). Nusa Jawa. Silang Budaya. Jakarta: Gramedia Pustaka Utama.

Lubis, Mochtar. (1988). Transformasi budaya untuk masa depan. Jakarta: Haji Masagung. 
Lukman, M.H. (1963). Adjakan PKI kepada kaum pengusaha nasional, (laporan tambahan wakil ketua I CC PKI kepada Sidang Pleno I CC PKI, disampaikan pada tanggal 11 Februari 1963). Djakarta: Jajasan Pembaruan.

Magnis-Suseno, F. (1984). Etika Jawa Sebuah Analisa Falsafi tentang Kebijaksanaan Hidup Orang Jawa. In PT Gramedia Pustaka Utama.

Majid, Nurcholish. (1968). Modernisasi adalah rationalisasi, bukan Westernisasi. Bandung: Mimbar Demokrasi Press.

Semma, Mansyur. (2008). Negara dan korupsi. Pemikiran Mochtar Lubis atas negara, manusia Indonesia, dan perilaku politik. Jakarta: Yayasan Obor.

Masduqi, A. (1964). Ke arah modernisasi pendidikan dan pengadjaran agama Islam di Indonesia. Jogjakarta: Panitia Refreshing Course Guru Agama

Mashuri. (1973). Masalah-masalah yang melandasi pembaruan pendidikan. Jakarta: Humas Departemen Pendidikan dan Kebudayaan.

Moertopo, Ali. (1973). Dasar-dasar pemikiran tentang akselerasi modernisasi pembangunam 25 tahun: (rangkuman ceremah, diskusi dan wawancara). Jakarta: Centre for Strategic and International Studies / Yayasan proklamasi.

Natsir, Tatang M. (1972). Di sekitar reformasi dan modernisasi masjarakat Islam. Bandung: Alma'arif2.

Nilan, Pam. (2020). Muslim youth environmentalists in Indonesia. Journal of Youth Studies, 24(4), 1-16.

Johanna, Njonja. (1896). Boekoe masakan baroe menoendjoekken bagimana bikinnja segala roepa makanan dan kwé-kwé jang enak tjara Blanda, Tjina, Djawa, Prasman dan laen-laen sebaginja menoeroet recept jang soedah terkoempoel. Batavia: Albrecht \& Co.

Noer, Deliar. (1988). Perubahan, pembaruan, dan kesadaran menghadapi abad ke-21. Jakarta: Dian Rakyat.

Eddy, Nyoman Tusthi. (1984). Pengantar singkat keragaman dan periodisasi pembaruan puisi Indonesia. Ende: Nusa Indah.

Ozu, S. 1943 (2003). Djiwa baroe. Bandung: Tjahaja

Partai Komunis Indonesia. 1962. Kita tjinta damai, takapi lebih tjinta kemerdekaan gerakan perdamaian dunia dan gerakan pambebasan nasional. Djakarta: Jajasan Pembaruan.

Rath, Amanda K. (2011). Contextualizing 'contemporary art': propositions of critical artistic practice in seni rupa kontemporer in Indonesia. New YOrl: Cornell University.

Rifai, Bachtiar. (1970). Islam dan pembaharuan: renungan untuk pendidikan tinggi Islam dalam menudju modernisasi Indonesia. Djakarta: Direktorat Djenderal Pendidikan, Departemen Pendidikan dan Kebudajaan.

Yuliantri, Roma Dwi Aria. (2021). “Jajasan 'Pembaruan': propaganda discourse through its printed products”. Informasi, 51(1), 27-44.

Shamad Hamid, A. (1984). Islam dan pembaruan: sebuah kajian tentang aliran modern dalam Islam dan permasalahanya. Surabaya: Bina Ilmu.

Simatupang, T.B. (1972). Komunikasi, konfrontasi, modernisasi dan negara Pancasila yang membangun. Jakarta: Yayasan Komunikasi. 
Soeharto. (1987). Keterangan Pemerintah tentang Rancangan Anggaran Pendapatan dan Belanja Negara Tahun 1987 dan 1988 pada Sidang Dewan Perwakilan Rakyat. Jakarta: Dewan Perwakilan Rakyat.

Soemardjo, Soepeno. (1990). Mikhail Gorbachev tokoh pembaruan abad ini. Jakarta: Pustaka Yayasan.

Studi Club "Mahasiswa Indonesia". (1968). "Modernisasi" dan peranan intelegensia dalam negara-negara jang sedang berkembang. Bandung: Studi Club "Mahasiswa Indonesia".

Teeuw, A. (1967). Modern Indonesian Literature. The Hague: Nijhoff.

Todaro, Michael P / Stephen C. Smith. 2020. Economic development. Harlow: Pearson. 